\title{
West African yam food technologies: prospects and impediments to change
}

\author{
Felix I. Nweke \\ Michigan State University \\ Corresponding Author's Email: nwekefel@yahoo.com
}

\section{ABSTRACT}

\begin{abstract}
Yam is an important commodity for more than 350 million people in West Africa because of its food, monetary and cultural values. The commodity is expensive compared with alternative starchy staples such as maize and cassava because of low technologies used in its production and postharvest handling. Yam storage techniques are rudimentary and redundant but vary from place to place depending on a range of circumstances including agro-ecology. Yam food is prepared mostly from fresh tuber by simple methods that have not changed over time and consumption is also simple because those yam foods can be eaten straight without a condiment. Compared with cassava the relative long postharvest shelf life; relative ease of food preparation from fresh tuber; and non-conventional uses of yam constitute disincentives for yam processing. Processed yam food is inferior substitute for the yam's fresh alternative; at the same time processed yam product is more expensive than processed cassava and grain products that are its substitutes.
\end{abstract}

Keywords: West Africa, Yam, Food technology, Food storage, Food preparation, Food processing

\section{INTRODUCTION}

In this paper food technology is understood to mean postharvest handling of food crops and animal products from storage through processing to food preparation. The paper aims to show that in West Africa yam food technology is traditional and except in one minor instance it has resisted change over time. Postulations on prospects and impediments to change in the technologies are made. The paper first defines the West African yam by distinguishing it from crops called yam in different parts of the world but which are not yam and discuses the method of the study. The paper goes on to explain the economic importance of the West African yam and to identify most common values of the commodity before discussing the yam food technologies under storage, food preparation and processing.

The paper is based mostly on primary data collected in the context of the yam consumption pattern in West Africa study (hereafter yam consumption study) commissioned by the BMGF (Bill and Melinda Gates Foundation) and executed from November 2012 to February 2013. In addition, the paper draws from secondary farm level studies as well as time series data published by the Food and Agriculture Organization of the United Nations (FAO) commonly referred to FAOSTAT (FAO Statistics).

\section{What is yam?}

D. G. Coursey defined yam by elimination of what is not yam but called yam in different parts of the world outside West Africa (Coursey 1967). In the United States of America, yam is commonly understood to be sweet potato. Yams are also often confused with edible aroids such as coco yams, taros, etc. outside of West Africa. In India, the elephant yam is an aroid, which is related to the coco yam, but not to yam. The word "yam" has also been used for the arrowroot and for several other edible starchy roots, tubers, or rhizomes grown in the tropics. Some leguminous plants that have swollen edible roots are described as yam beans. In the sense that the word is used in this paper, all yams are members of the monocotyledonous Dioscoreaceae family; virtually all belong to the genus Dioscoreaceae. The genus Dioscoreaceae is made up of some 600 species, but only about 10 of them produce edible tubers (Ene and Okoli 1985). Of these four referred to as white yam, water yam, yellow yam and aerial yam are of economic importance.

The majority of Dioscoreaceae that are of economic importance produce one or more tubers underground, which are often renewed annually; few of the Dioscoreaceae such as aerial yams, which produce 
tubers above the ground, are exceptions. Above the ground, yam growth, which is usually annual, consists of twining vine-like morphology that requires support from neighboring vegetation or a stake (Watt 1961).

\section{Method of the yam consumption study}

The yam consumption study was conducted in four purposely selected countries-namely, Burkina Faso, Ghana, Mali, and Nigeria representing West Africa. In 2010, the four countries accounted for more than 70 percent of the population of West Africa and more than 85 percent of the West African yam supply (FAOSTAT). Nigeria and Ghana are respectively the largest and second largest yam producers worldwide; Mali and Burkina Faso are marginal yam producing counties.

In each representative country, a nationwide food consumption survey was conducted. Time and money available for the study were tight; there was barely four months from November 8, 2012 to February 28, 2013 to complete the survey and the financial budget for the nationwide food consumption survey was zero. Without a nationwide food consumption survey, analyses of yam consumption patterns would only be speculative and nonfactual because of the scanty information in yam literature for West Africa.

The food consumption surveys were conducted by telephone in all four countries. In each country, a number of telephone enumerators were engaged. Enumerators interviewed their telephone contacts using a single row structured questionnaire. Information collected included location, gender, income group of the respondent, and number of times the individual respondent ate each of the major staples in the preceding seven days; some of the staples were broken down into specific food products. Location, gender, and income were known to the enumerator a priori because the respondent was a telephone contact. Based on personal knowledge, the enumerator assigned a respondent to a lower, medium, or upper income group. Therefore the income grouping of the respondents is not unique among enumerators. The telephone interview was efficient; a short and simple telephone interview guaranteed wide geographical coverage in a cost effective manner.

In the major yam-producing countries, i.e. Nigeria and Ghana, farmers were interviewed in groups in different yam agro-ecologies. A group consisted of a minimum of ten farmers widely ranging in age, including the oldest in the community. In Nigeria, the farmer group interviews were conducted in Otuocha, which is known for seed yam and ceremonial yam productions along the River Niger basin; Zaki Biam in the derived savanna agro-ecology; and in Shaki, north of Ibadan, which is celebrated as the largest source of traditional yam flour called amala. Farmer groups were also interviewed in Kintamkpo in central Ghana and in the Tamale area in northern Ghana.
Information was sought from the farmers on yam production, harvesting, and post-harvesting handling technologies, and on the uses of yam apart from selling and home consumption.

In a major yam market in each study country, a survey was conducted to perfunctorily assess the volume and determine, through the interview of merchants, the origin of yams available for sale. In Ibadan, Nigeria, processed yam products, namely amala (traditionally prepared yam flour) and poundo yam (industrially prepared yam flour) and their substitutes, namely semo (industrially prepared flours of grain) and gari (granulated cassava product) were purchased to determine their prices at retail value. The retailers were interviewed for their assessment of purchaser preferences for those products. Prepared food made of yam, namely foutou (pounded yam) and its substitutes, namely to (maize meal) and riz (rice meal) were bought in a popular restaurant in central Ouagadougou, the capital of Burkina Faso, to determine prices. In the market in Kumasi, Ghana, yam, fresh cassava roots, and maize grains were purchased to determine their prices at retail value.

\section{Economic importance of yam in West Africa}

In West Africa, yam is appreciated by so many people, is part of the traditional diet of many and is central in cultural rites that are important for the existence of the people in producing areas individually and communally. Yam has been described as the most African of all African crops (Kiene 2016). Africa's contributions to global supplies of grains are modest: maize, about five percent; rice, three percent; and wheat, three percent in the late 2000s (FAOSTAT) FAOSTAT stands for Food and Agriculture Organization of the United Nations Statistics. However, Africa is the lead player in terms of the production of yam: more than 90 percent of global yam production happens in Africa.

West Africa is a region with an estimated population of 350 million people in the year 2014 with annual compound growth rates of around two percent (FAOSTAT). Most of these populations are dependent on arable crop agriculture, and derive large percentages of their food calorie intake and cash income from root and tuber crops, mostly cassava, yam and sweet potato.

In West Africa, yam is expensive compared with other starchy stapes such as maize and cassava because low technologies are used in the yam food crop sector. In Ghana, the consumer price of yam is highest, by a large margin, among the major starchy staples (Figure 1). The yam food crop sector does not benefit from government food crop development programs which are based on available technologies (Nweke 2016). Yam seed technology is low; there are no high-yielding yam varieties at the farm level; production and harvesting of yam are not mechanized; and yam storage technology is 
042 Afr. J. Food Sci. Technol.

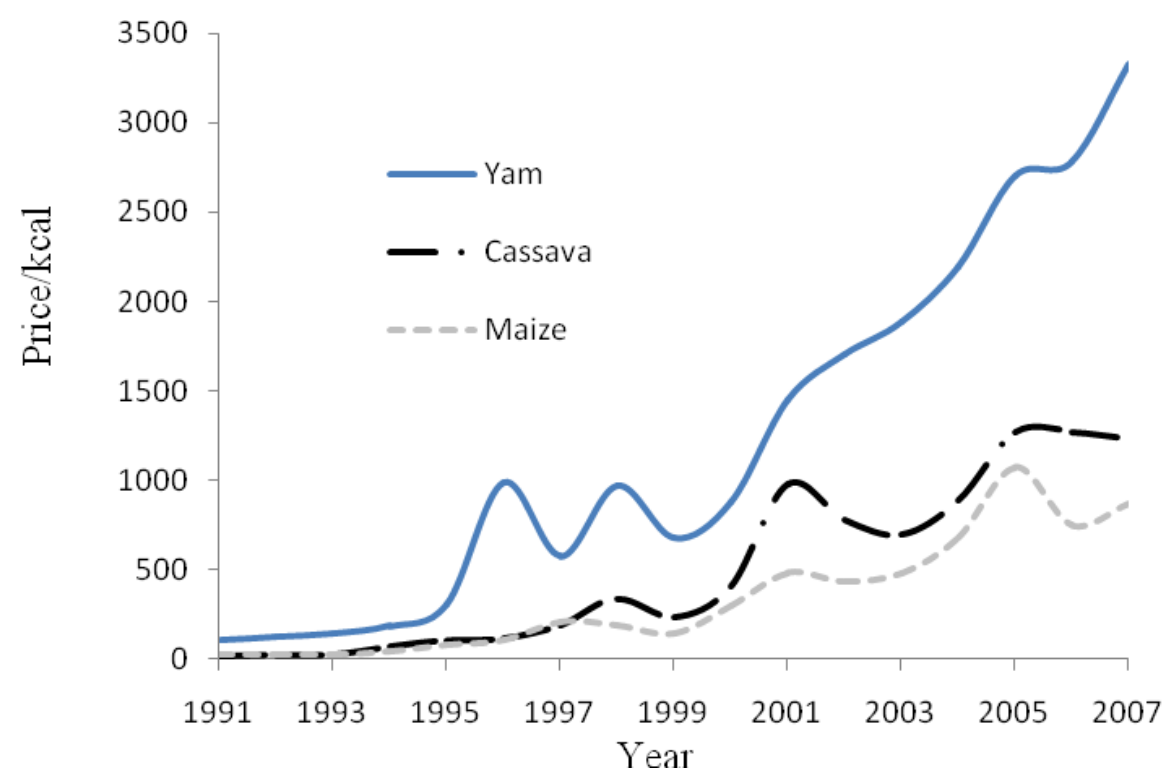

Figure 1. Ghana: Consumer prices of yam, rice, cassava and maize (Cedis at current prices), 1991 to 2007. Source: FAOSTAT.

Table 1. West Africa: Average carbohydrate, protein and fat per $\mathrm{Kg}$ in yam, cassava, sweet potato, maize, rice and pulses. Source: FAOSTAT

\begin{tabular}{llll}
\hline Commodity & Carbohydrate (Kcal.) & Protein $(\mathbf{G m})$ & Fat $(\mathbf{G m})$ \\
\hline Yam & 985 & 15.9 & 1.87 \\
Cassava & 909 & 5.9 & 1.56 \\
Sweet potato & 929 & 11.6 & 3.87 \\
Maize & 3103 & 81.7 & 86.30 \\
Rice & 3636 & 73.4 & 7.55 \\
Pulses & 3360 & 220 & 16 \\
\hline
\end{tabular}

rudimentary. Yam is not part of the credit subsidy program extended to farmer groups in Ghana because of the rudimentary storage technology. Loan recovery through crop purchase and stockpiling also in Ghana is not feasible in the case of yam because the crop cannot be stored on a large scale in one location because of the low storage technology.

\section{Values of yam in West Africa}

\section{Nutritional Value}

Questions are often raised in agriculture R\&D (research and development) circles in West Africa concerning the nutritional value of yam, especially when measured against cassava, which is reputed as a low-cost source of food calorie (Nweke, Spencer and Lynam 2016). These questions raise doubt among African policy makers and international donor organizations regarding the rationale for investment in yam $R$ and $D$. Their reasoning is that a unit of investment is more profitable, in terms of food calories produced, in cassava than in yam.

The main nutritional value of yam, cassava and other root and tuber crops is food calorie. This is because the starchy staples are considerably lower in protein and fats than pulses and grains (Table 1). The margin of difference in calorie content between cassava and yam which is in favor of yam is low enough that production cost per unit of calorie is likely to be lower from cassava than from yam since yam is more expensive than cassava (Nweke 2016). Protein content is considerably higher in yam than in cassava; yet yam is not a major source of protein when weighed against pulses and grains. Similar comparisons are obtained with respect to fats.

In conclusion, cassava is likely to be a cheaper source of calorie than yam. But the fact that yam has a considerably larger amount of protein and perhaps more 
Nweke, 043

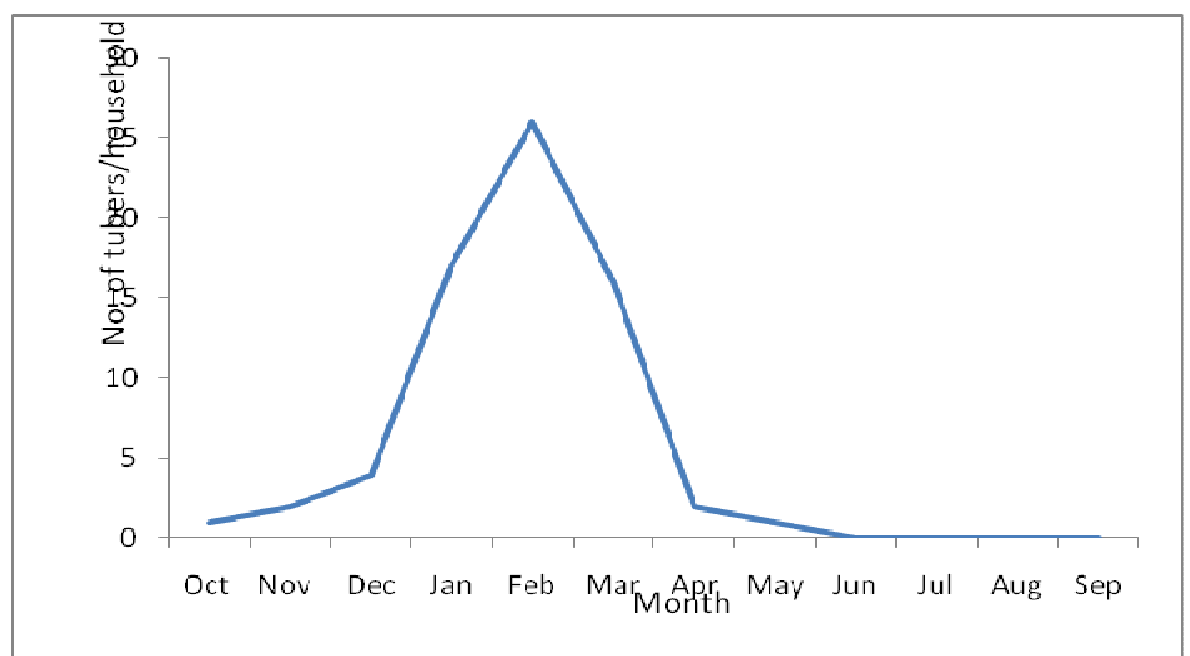

Figure 2. Eastern Nigeria: Average number of yam tubers in storage per household by month. Source: Ugwu 1990.

calories as well as fats per unit weight than cassava is clearly sufficient justification for addressing the underlying causes of high yam production costs.

\section{Market value}

In West Africa, yam is produced more for sale than for home consumption. In both Nigeria and Ghana 60 percent of the yam harvest, after discounting for seed, is sold and only 40 percent is consumed in the farmers' households (Mignouna et al. 2014). The crop is widely produced with purchased inputs, especially hired labor. Yam responds positively to the application of purchased inputs in terms of yield and land area expansion, which shows that the potential for improvement is high if R\&D measures are implemented to improve production technologies. It shows that farmers will readily adopt new yam production technologies that can solve felt needs and drive down production costs.

\section{Non-conventional cultural value}

Introductions in several yam literatures in West Africa acknowledge that yam has an important role in the culture of the people in major producing areas in the region (Hahn et al.1987 and Nweke 2016). Demand for yam for use as a ritual object in cultural rites of passage, thanksgiving, petition and appeasement practiced in major producing and consuming centres is high enough to produce significant effect on yam consumption.

\section{Yam storage techniques}

Yam storage techniques vary from place to place depending on a range of circumstances including security and agro-ecology. Common yam storage techniques in yam producing centres in West Africa are piling in thatched mud huts with perforated walls, tying on racks and piling up in dry material covered heaps (Photograph 1). All the storage techniques date back to time not remembered by anyone in farmer group that were interviewed in major yam producing areas in Nigeria and Ghana in the context of the yam consumption study (Nweke, Aidoo and Okoye. 2013). Each farmer group included the oldest farmer in the area. Therefore yam storage techniques vary in space but not in time; different yam producing areas have different techniques that have not changed.

Each existing yam storage technique has upside and downside; security and enhanced aeration, especially in high humidity environments are the main advantages of storage by tying on racks at home while high labor requirement is the major drawback of that method. In less humid environments, storage in thatched hut or in covered heap is preferred because of its less labor need. But these methods expose yam to pests and diseases.

Under existing yam storage technologies, the crop is not storable from one harvest season to another because the crop has limited postharvest shelf life of three to six months depending on variety. Dr. Boniface Ugwu of the Nigerian National Root Crops Research Institute took a course route approach to measure net quantity of yam brought in less quantity taken out of store among farmers in Eastern Nigeria (Ugwu 1990). Dr Ugwu's data reveal that stock began to accumulate in October early in the harvest season, peaked in February towards the end of the harvest season and thereafter diminished to zero in June or July (Figure 2). Literature did not provide evidence that this information has been updated in another study. Farmers sell off their yams within a few months after harvest to avoid storage losses that are caused mainly by yam pests and diseases of which 


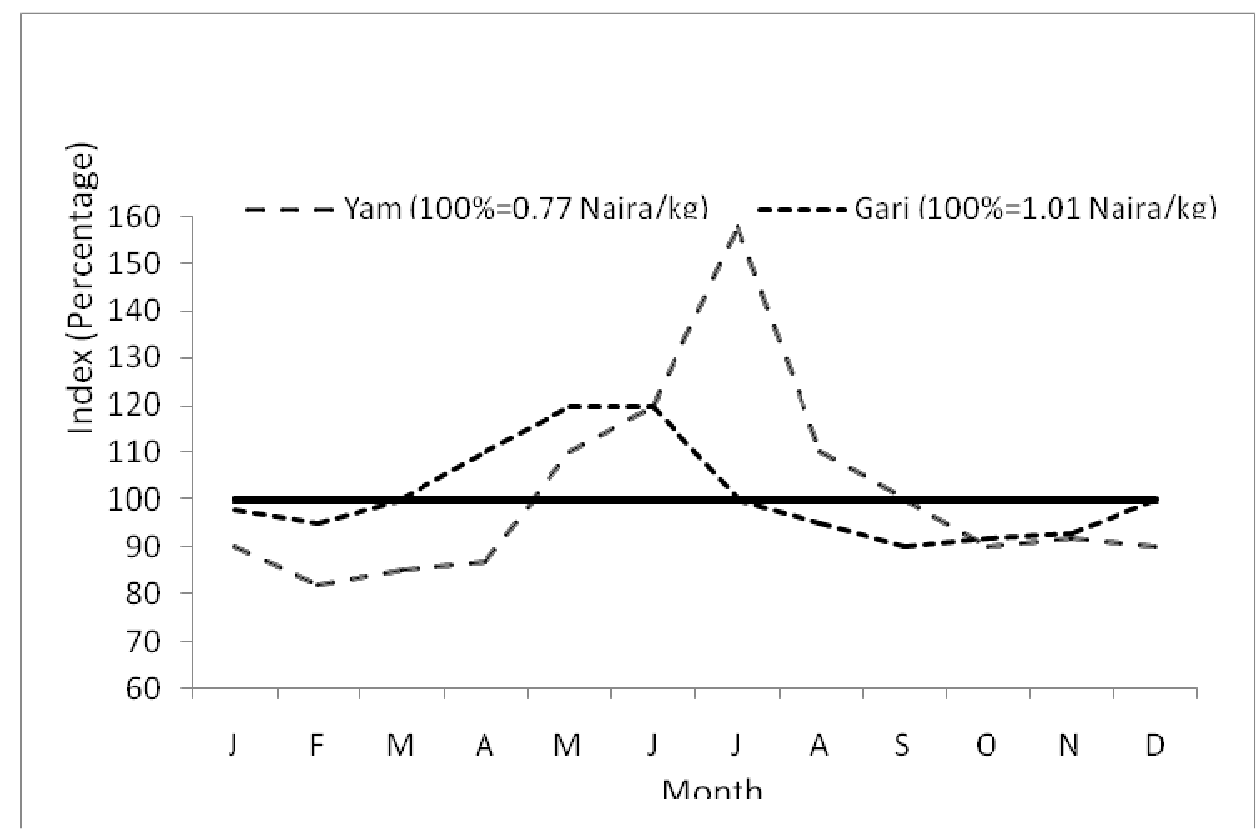

Figure 3. Eastern Nigeria: Indices of monthly average retail prices of yam and gari (cassava product). Source: Ugwu 1990

nematodes and viruses are the most damaging ones. The problems of yam nematodes and viruses have dogmatically defied solution (Nweke 2016). Off farm yam storage is minimal; yam marketing channel is weak in terms of rural assembly and wholesale warehousing (Nweke 2016). Most yams for sale move directly from the farm through wholesale and retail markets to consumers as fast as possible for fear of losses through pest and disease attack (Amikuzuno 2001). Yam pests and diseases, especially nematodes and viruses are the key impediments to change in yam storage technologies.

The result of the inability of existing storage technologies to hold yam from one harvest to another is seasonality in supply and in market prices. This situation results in capital losses to producers who sell most of their yam at low prices during harvesting period and to consumers who pay high prices after harvesting period. Figure 3 compares indices of average monthly retail market prices of yam with that of cassava in Eastern Nigeria. The coefficient of variation is considerably higher in the case of yam, 7.83 than cassava, 1.30; cassava is harvested all year round because it is not a seasonal crop.

In the absence of solutions to the problems of the major yam pests and diseases, can a technology be developed that can standardize yam storage methods across ecologies and be able to hold yam in good condition from one harvest to another? Such a technology will reduce storage losses and also reduce capital losses to producers who sell most of their yams at low prices during harvesting period and consumers who pay high prices after the harvesting period. Such technology will permit yam storage off farm so that traders can perform speculative market function and enable farmers to concentrate on the production business.

\section{Yam food preparation methods in West Africa}

In West Africa, yam food is prepared mostly from fresh tuber. Fresh yam tuber can be prepared into food forms such as roasted yam (grilled), boiled yam (cooked in water), pounded yam (boiled yam pounded) and fried yam (cooked in oil). Of the four yam consumption study countries, namely Burkina Faso, Ghana, Mali and Nigeria the latter is the center of diversification of fresh yam food preparation; all four yam foods are common in the country. In the country average frequencies of consumption were 65 percent from fresh tuber, 25 percent from product processed in the traditional sector and only 10 percent from product processed industrially (Figure 4). In Burkina Faso only fried yam was reported consumed by consumers interviewed in the yam consumption study; Ghana, more than 95 percent reported boiled yam; and in Mali 55 percent reported boiled yam, 30 percent fried yam an 15 percent roasted yam (Figure 5). Reports of processed yam products were rare in Ghana and not at all in Burkina Faso and Mali.

Preparation as roasted yam or boiled yam is simple and consumption can also be simple because those yam 
Nweke, 045

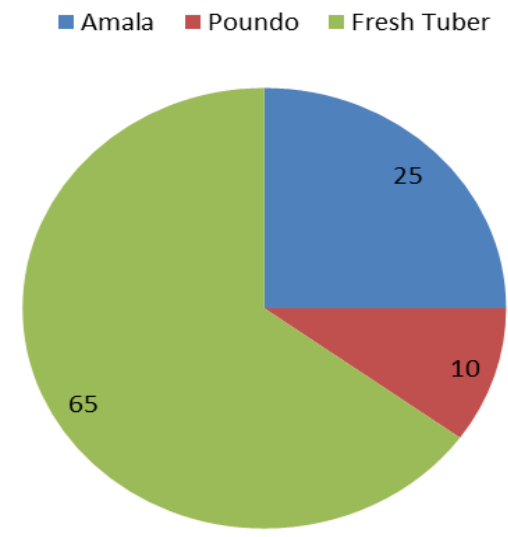

Figure 4. Nigeria: Percentage frequencies of consumption of yam food prepared from fresh and processed yam products. Source: Yam Consumption Study.

foods can be eaten straight without a condiment. The cooking methods must have been adopted when man discovered yam, probably in Eastern Nigeria that is reputed as the center of origin of the white yam (Coursey 1967). Unlike most common varieties of cassava that must be pre-processed before cooking edible species of yam are safe for human consumption after simple cooking though some animals and birds safely eat them raw. There is a high likelihood that the early man first prepared yam for consumption by roasting it in open fire with firewood that must have been in abundance in his environment and later by boiling in water. Pounded yam and fried yam preparation methods must have followed when man's food consumption habit became more sophisticated.

As a tuber crop in unprocessed form yam has high water content and short shelf-life compared with in processed forms that will have low water content and supposedly long shelf-life. The high water content and short shelf-life characteristics are drawbacks which impede bulk purchase for home use that reduces the frequency of shopping which is of interest to working class homemakers. Bulk purchases have price discount advantage that is also of importance to purchasers.

Fresh yam is unstable in all cooked forms; cooked yam foods lose quality when not warm. Therefore fresh yam is cooked in small quantities in order to be consumed within the shortest period of time to avoid waste, with implications for yam as restaurant food. To eat any of the fresh yam foods in popular restaurants that serve it, one must go early in the afternoon, or else the prepared food runs out. In hotel restaurants, fresh yam food products are served a la cat.

So why is yam food more commonly prepared from fresh than in processed form? Possible reasons include relative ease of fresh yam food preparation, consumer income and large rural population, non-conventional value of the yam crop and low yam food processing technology. In certain respects fresh yam tuber is more convenient to prepare into various yam foods in comparison with grains and legumes. Roasted yam, boiled yam and fried yam cook faster and therefore use less energy and time than most grains and legumes. Among the yam consumption study countries income is low and skewed compared with some Latin American and Asian countries such as Brazil and Thailand (Table 2). Similarly most of the population in the majority of the yam consumption study countries is rural based. Rural based and low income populations are more likely than medium to upper income urban populations to have preference for yam foods prepared from fresh tuber. Low income rural populations are more likely to be engaged in farming as self-employed and therefore have more time to devote to food preparation than urban working class populations who work off-farm, some as wage workers. Yam is used in fresh form for cultural rites of passage, thanksgiving, petition and appeasement practiced in major producing and consuming centers in West Africa. The amounts of yams used for the purpose each year are sufficient to constitute a significant demand for fresh yam because each year the numbers of marriages, births, and funerals in both rural and urban settings are high. These are in addition to a litany of heathen shrines that demand and receive tributes of fresh yam daily for thanksgiving, petition, and appeasement.

\section{Yam processing}

In West Africa, yam faces the challenge of high cost in food industries. Often at yam conferences, workshops, and related gatherings, food scientists excitedly display 
046 Afr. J. Food Sci. Technol.
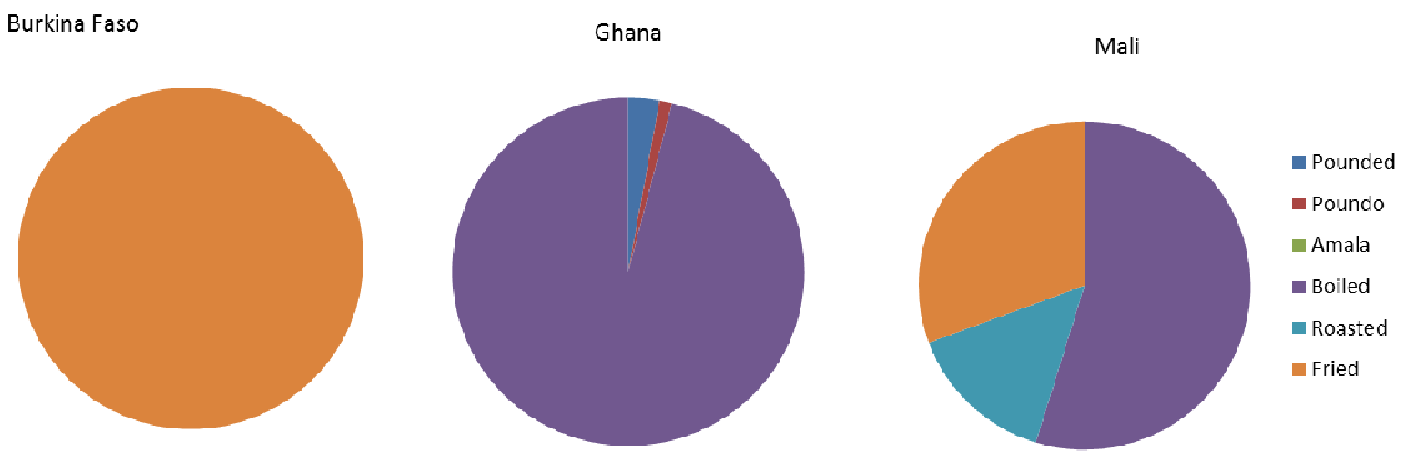

Figure 5. Burkina Faso, Ghana and Mali: Percentage frequencies of consumption of yam food products. Source: Yam Consumption Study.

Table 2. Major yam producing countries in Africa: Some economic indicators.

\begin{tabular}{lrrr}
\hline Country & $\begin{array}{r}\text { Poverty Head } \\
\text { Count Ratio }^{{ }^{1}}\end{array}$ & $\begin{array}{r}\text { GDP/Cap } \\
{\text { (US } \$)^{2}}^{2}\end{array}$ & $\begin{array}{r}\text { Rural Population as \% } \\
\text { of Total }^{3}\end{array}$ \\
\hline Nigeria & 53.47 & 3,082 & 52 \\
Ghana & 25.15 & 1,871 & 46 \\
Mali & 49.25 & 646 & 60 \\
Burkina Faso & 43.73 & 711 & 70 \\
Brazil & 3.66 & 11,173 & 14 \\
Thailand & 0.04 & 5,676 & 50 \\
\hline
\end{tabular}

$\%$ of population at US\$1.90/day, 2011. Source:

1.World Bank Development Research Group based on primary household survey data.

2.IMF World Economic Outlook database. Latest year for which data is published.

3.World Bank, rural population as \% of total population 2015

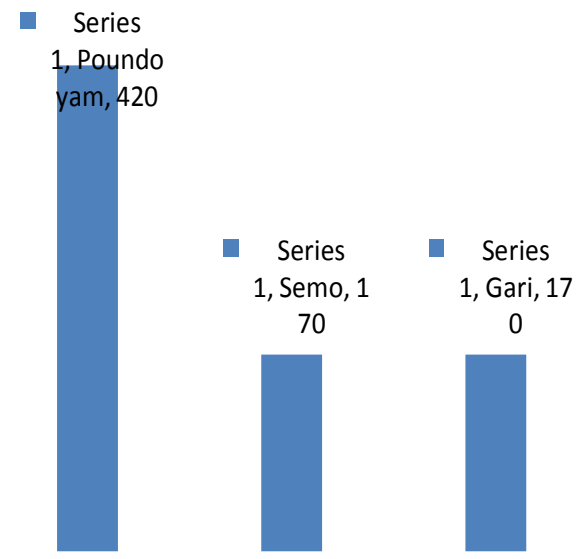

Figure 6. Nigeria: Retail prices (Naira/Kg. 160 Naira=US\$1.00) of poundo yam, semo and gari in Bodija market, Ibadan, December. Source: Nweke, Aidoo and Okoye 2013.

pastry products made from yam flour as was done at the Global Yam Conference, October 2013, Accra Ghana and at YIIFSWA Progress Review and Work Planning
Meeting, February 2014, IITa, Ibadan, Nigeria.. Such excitements are justified because the products are proof 
Nweke, 047

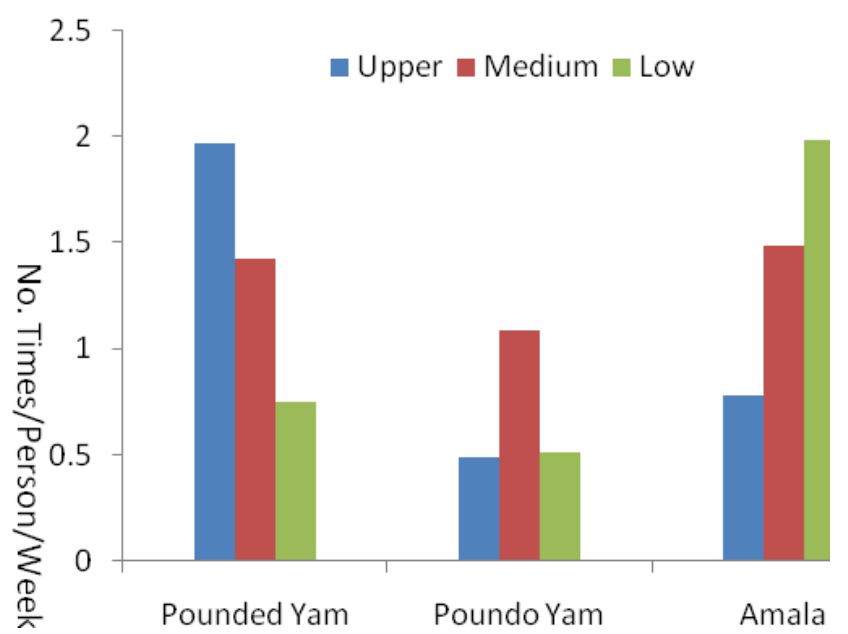

Figure 7. Nigeria: Frequencies of yam consumption (number of times/person/week) by yam food products by relative income group, December 2012. Source: Nweke, Aidoo and Okoye 2013.
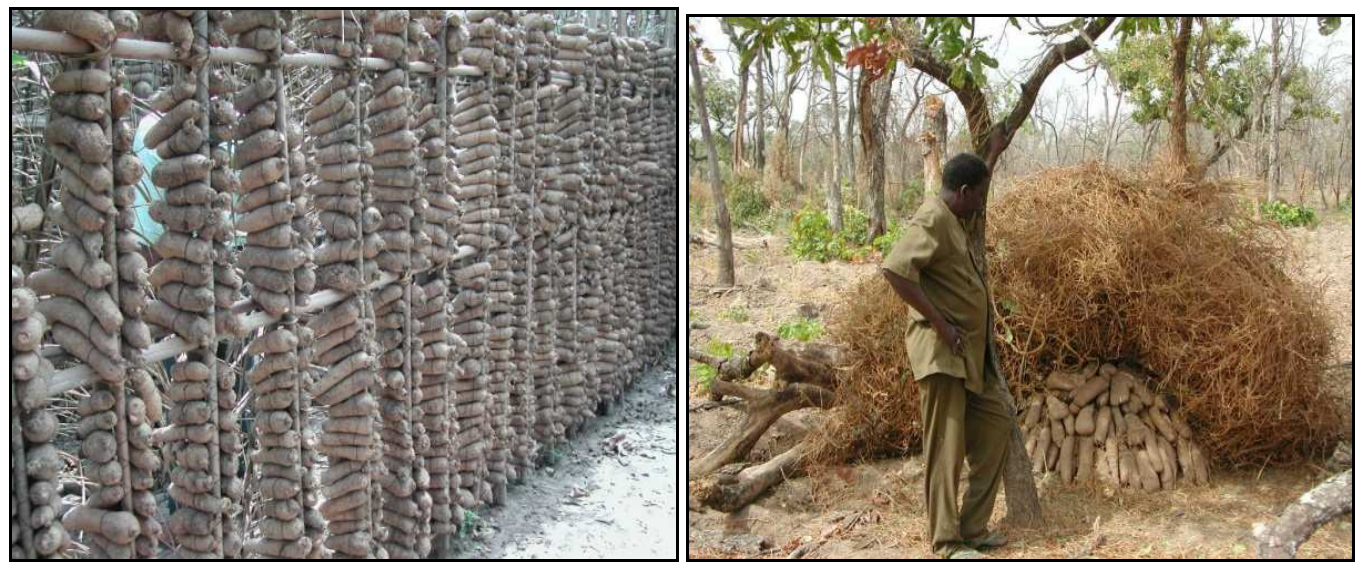

Photograph 1. Yam storage technologies, racks and heap. Source: Coyne, Claudius-Cole and Kikuno. 2010.

that making pastries from yam flour is technically feasible, but economic feasibility needs to also be established to consummate the excitement. That can be done by bringing the cost of yam down to the cost levels of cassava and imported grains which are used to prepare pastries.

Poundo yam and amala are the only processed forms of yam; both are dried tuber flour for preparation as foofoo. A common African food pattern is called foofoo in Anglo-phone West Africa, foutou in Franco-phone West Africa, ugali in East Africa and nsima in Southern Africa. Yam consumed in any other food form is prepared from fresh tuber. Poundo yam is prepared industrially and amala is prepared in the traditional sector (Photograph 2). During the yam consumption survey Poundo yam was observed in Nigeria but not in Ghana, Mali or Burkina Faso. Amala is a common yam food product in parts of Western Nigeria. Poundo yam has alternatives, namely semo (industrially prepared grain flour) and granulated cassava food product called gari both of which are also prepared as foofoo. Of the three, poundo yam is the most expensive; its price at the retail level is triple the prices of its two competitors (Figure 6). Both poundo yam and amala are inferior substitutes for pounded yam foofoo.

The consumption frequency of pounded yam increased from low income group through medium income group to upper income group (Figure 7). Some members of the medium income group who could not afford pounded yam settled for poundo yam or more likely for semo and gari. Affordability of pounded yam 
048 Afr. J. Food Sci. Technol.

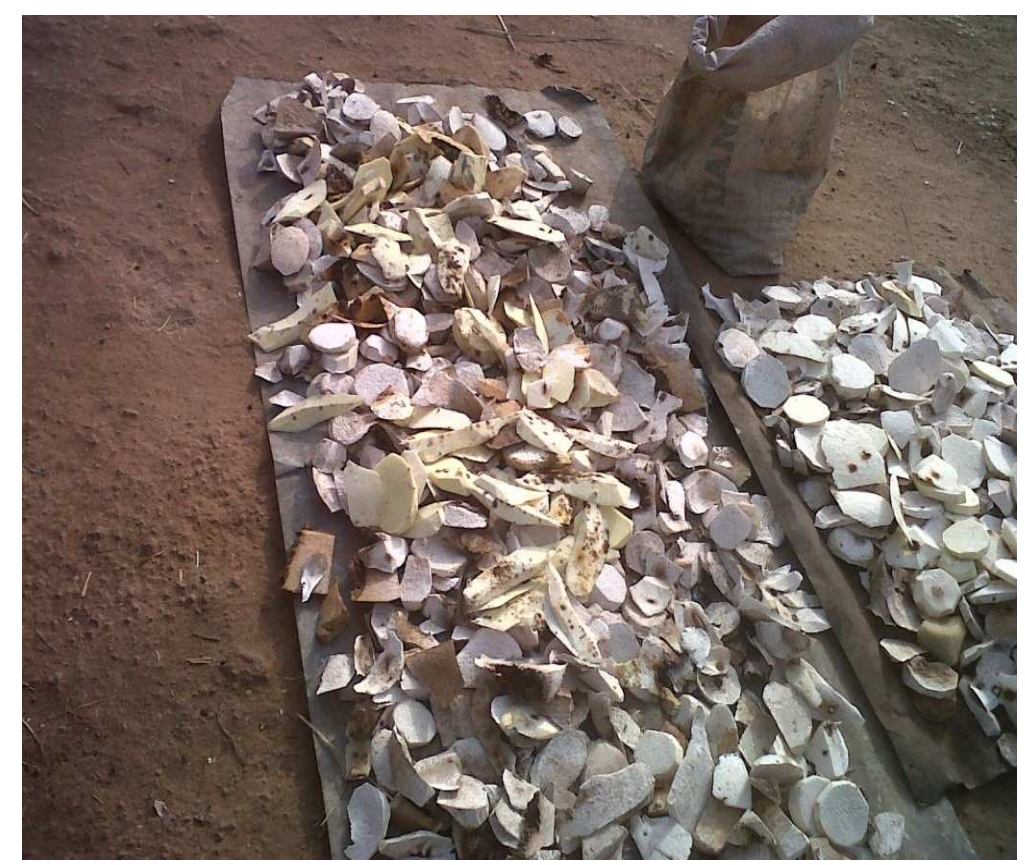

Photograph 2. Chips of yam tuber being sun dried for making amala in the traditional sector.

includes having facility for pounding. Apartment buildings are not suitable for pounding yam because the pounding can shake such buildings and the noise can disturb neighbors. The consumption frequency of amala decreases from the lower income group among whom it is highest through medium income group to the upper income group among whom the frequency is lowest because the processing method is traditional and can turn off some upper and medium income consumers.

Quality instability is an encumbrance on poundo yam consumption. Packaged poundo yam was not common in Nigerian markets. Traders interviewed during the yam consumption study revealed that when sales were delayed, the product deteriorated because poundo yam was more susceptible to weevils and fungi than grain flours. The traders explained that demand was low because of high cost and because consumers have access to the real thing, namely pounded yam.

In summary, the ability of simple cooking methods to eliminate poisonous substances in edible yam species is an impediment to progress in yam processing technology. Further impediments are Consumer preference for yam food prepared from fresh tuber and high cost of processed yam food products compared with substitutes such as processed cassava and grain food products are further impediments to progress in yam processing technology. Processed yam food is inferior substitute for fresh yam alternative because consumers prefer food prepared from fresh yam. But at the same time processed yam product is more expensive than its substitutes made from cassava and grains.

\section{Impediments and prospects for change in West African yam food technologies: a synthesis}

Yam postharvest losses owing to pests and diseases, particularly the problems of nematodes and viruses impede change in yam storage technologies. Consumer preference for yam food prepared with fresh yam to food prepared with yam processed product is a key impediment to processing of yam. Other impediments to yam processing include high cost of processed yam compared with its substitutes made with cassava and grains; relative ease of yam food preparation from fresh tuber compared with grains and legumes; the fact that yam is save for human consumption after simple cooking; relative long postharvest shelf life of up to three months depending on variety compared with cassava, two or three days of postharvest shelf life; non-conventional uses of yam that are always in fresh form; and large rural low income urban populations.

Development of technologies to control yam postharvest losses due to pests and diseases problems such as nematodes and viruses can help bring about change in yam storage technology. Improvement in consumer income with growth in the working class middle income group will promote demand for processed yam food products which are more convenient to prepare into meals than fresh tuber. Food technologies that can make poundo yam quality competitive with pounded yam will provide a good prospect for yam food processing in West Africa. Development of technologies for processing yam into forms that can be prepared as boiled, fried and 
grilled yam that can perhaps stabilize their qualities in cooked form will provide further prospects for yam food processing in West Africa. Most importantly, development and dissemination of technologies that can drive down yam production costs and make the commodity price competitive with alternative staple substitutes such as cassava and maize will encourage change in yam food technologies.

\section{REFERENCES}

Amikuzuno, Joseph (2001). Evaluating the efficiency of the yam marketing system in Ghana. M. Phil. Thesis. Department of Agricultural Economy and Farm Management, University of Ghana, Legon.

Coursey , DG (1967). Yams. Longmans, London. Xiv+230. Coyne D, A Claudius-Cole, H Kikuno (2010). Sowing the seeds of better yam. CGIAR SP-IPM Technical Innovation Brief, No. 7, November, 2010.
Hahn SK, DS Osiru, MO Akoroda, JA Otoo (1987). Yam production and its future prospects. Outlook on Agriculture 16(3): 105-110.

Kiene, Werner (2016). "Foreword" in Yam in West Africa: Food, Money and More. Felix I. Nweke. Michigan State University Press, East Lansing.

Mignouna, Djana, Adebayo Akinola, Issacq Suleman, Felix Nweke (2014). Yam: A Cash Crop in West Africa. YIIFSWA Working Paper No. 3. IITA, Ibadan. Nweke, Felix I (2016). Yam in West Africa: Food, Money and More. Michigan State University Press, East Lansing.

Nweke, Felix I, Robert Aidoo, Benjamin Okoye (2013). Yam consumption patterns in West Africa. Unpublished report prepared for Bill and Melinda Gates Foundation .

Ugwu, Boniface Omans (1990). Resource use and productivity in food crop production in major yam producing areas of southeast Nigeria. Ph D thesis, University of Nigeria, Nsukka, Nigeria. 